\title{
Homenagem à Professora Lilian Vilela Andrade Pinto
}

Lilian Vilela Andrade Pinto é professora do IFSULDEMINAS (Instituto Federal de Educação, Ciência e Tecnologia do Sul de Minas Gerais), campus Inconfidentes, onde leciona em pós-graduação, graduação e nível técnico. Coordenou projetos de pesquisa dos quais resultaram publicações na área de manejo ambiental e engenharia florestal. Destacou-se como orientadora de trabalho de conclusão de curso de graduação premiado em $2^{\circ}$ lugar no "9 Prêmio Ouro Azul de Furnas", promovido pelo jornal "Estado de Minas". Também foi orientadora de projeto classificado na etapa regional do "Prêmio Técnico Empreendedor".

Natural de Lavras, Minas Gerais, a professora Lilian ingressou em 1996 na graduação em Engenharia Florestal da UFLA (Universidade Federal de Lavras), que concluiu em 2001. Ainda na UFLA, terminou mestrado em 2003 e doutorado em 2007, ambos na área de manejo ambiental.

Estudou várias áreas da engenharia florestal, destacadamente manejo ambiental, manejo de bacias hidrográficas e germinação de sementes, apresentando resultados de sua pesquisa de doutorado em evento que contou com palestrantes estrangeiros especialistas na área de sementes, como Peter Toorop, pesquisador do Millennium Seed Bank da Inglaterra, e Henk Hilhorst, da Universidade de Wageningen da Holanda.

Em 2005, obteve aprovação em concurso público para professora efetiva de meio ambiente na antiga Escola Agrotécnica Federal de Inconfidentes, hoje campus Inconfidentes do IFSULDEMINAS.

Atuou desde então como coordenadora do curso superior de tecnologia em gestão ambiental e do curso técnico em meio ambiente dos polos de rede de São Gonçalo do Sapucaí, Itanhandú e Ouro Fino. Coordena o Escritório Local de Inovação e Transferência de Tecnologia (ELITT) do campus Inconfidentes, tendo como principais funções promover a cultura da inovação na comunidade e orientar sobre proteção do conhecimento conforme leis de propriedade industrial e direitos autorais.

A professora Lilian é membro da Comissão Própria de Avaliação (CPA), da Câmara de Pesquisa, Pós-Graduação e Inovação (CAPEPI), ambos do IFSULDEMINAS; e também do colegiado do curso de tecnologia em gestão ambiental do campus Inconfidentes, e da comissão local para implantar a Agenda Ambiental da Administração Pública (A3P).

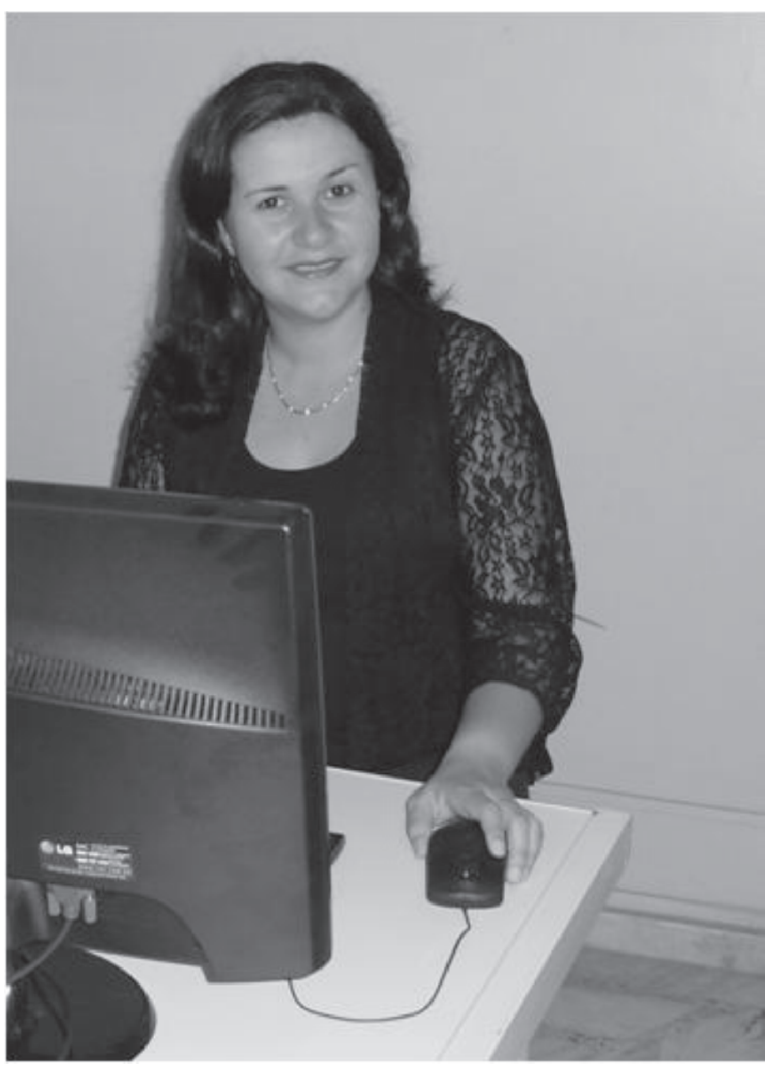

